\title{
Fentanyl-related overdose during incarceration: a comprehensive review
}

Eliana Kaplowitz ${ }^{1,2^{*}}$, Ashley Q. Truong ${ }^{3}$, Alexandria Macmadu ${ }^{1,4}$, Meghan Peterson ${ }^{5}$, Lauren Brinkley-Rubinstein 1,6, Nathan Potter ${ }^{7}$, Traci C. Green ${ }^{2,8,9}$, Jennifer G. Clarke ${ }^{10}$ and Josiah D. Rich ${ }^{1,2,4}$

\begin{abstract}
Background: Fentanyl and related compounds have recently saturated the illicit drug supply in the United States, leading to unprecedented rates of fatal overdose. Individuals who are incarcerated are particularly vulnerable, as the burden of opioid use disorder is disproportionately higher in this population, and tolerance generally decreases during incarceration.

Methods: We conduct a systematic search for publications about fentanyl overdoses during incarceration in PubMed and PsycINFO, as well as lay press articles in Google, from January 1, 2013 through March 30th, 2021.

Results: Not a single fentanyl overdose was identified in the medical literature, but 90 overdose events, comprising of 76 fatal and 103 nonfatal fentanyl overdoses, were identified in the lay press. Among the 179 overdoses, 138 occurred in jails and 41 occurred in prisons, across the country.

Conclusions: Fentanyl-related overdoses are occurring in correctional facilities with unknown but likely increasing frequency. In addition to the need for improved detection and reporting, immediate efforts to 1) increase understanding of the risks of fentanyl and how to prevent and treat overdose among correctional staff and residents, 2) ensure widespread prompt availability of naloxone and 3) expand the availability of medications to treat opioid use disorder for people who are incarcerated will save lives.
\end{abstract}

Keywords: Fentanyl, Opioid, Overdose, Incarceration

\section{Introduction}

Opioid use and incarceration are interrelated problems in the United States. Even prior to the current opioiddriven overdose epidemic, up to one-third of people who used heroin were incarcerated annually (Boutwell, Nijhawan, Zaller, \& Rich, 2007). Opioid use disorder (OUD) is more severe and advanced in justice-involved populations than in the general population (Winkelman, Chang, \& Binswanger, 2018). While incarcerated, individuals often undergo a period of reduced opioid use

\footnotetext{
* Correspondence: EKaplowitz@lifespan.org

'The Center for Health and Justice Transformation, The Miriam Hospital, Providence, RI, USA

${ }^{2}$ Center of Biomedical Research Excellence on Opioids and Overdose, The Rhode Island Hospital , RI, Providence, USA

Full list of author information is available at the end of the article
}

that may lead to a diminished physiological tolerance to opioids (Binswanger et al., 2007). Reduced tolerance has been identified as a significant contributor to risk for drug overdose following release from incarceration, and it is estimated that individuals released from incarceration have nearly 13 times the risk of death as the general population, with overdose as the leading cause (Binswanger et al., 2016; Brinkley-Rubinstein et al., 2018; Green et al., 2018).

Fentanyl and related compounds have recently emerged as the primary drivers of the opioid overdose epidemic in the United States, having saturated much of the illicit drugs (Increases in Fentanyl Drug Confiscations and Fentanyl-Related Overdose Fatalities, 2018; O’Donnell, Halpin, Mattson, Goldberger, \& Gladden, 2017; Ostling

(c) The Author(s). 2021 Open Access This article is licensed under a Creative Commons Attribution 4.0 International License, which permits use, sharing, adaptation, distribution and reproduction in any medium or format, as long as you give appropriate credit to the original author(s) and the source, provide a link to the Creative Commons licence, and indicate if changes were made. The images or other third party material in this article are included in the article's Creative Commons licence, unless indicated otherwise in a credit line to the material. If material is not included in the article's Creative Commons licence and your intended use is not permitted by statutory regulation or exceeds the permitted use, you will need to obtain permission directly from the copyright holder. To view a copy of this licence, visit http://creativecommons.org/licenses/by/4.0/ The Creative Commons Public Domain Dedication waiver (http://creativecommons.org/publicdomain/zero/1.0/) applies to the data made available in this article, unless otherwise stated in a credit line to the data. 
et al., 2018; Reported Law Enforcement Encounters Testing Positive for Fentanyl Increase Across US | Drug Overdose | CDC Injury Center, 2019; U.S. Drug Overdose Deaths Continue to Rise; Increase Fueled by Synthetic Opioids, 2019). As evidenced by toxicology reports and personal accounts from people who use illicit substances, illicit fentanyl is often mixed with heroin-although it has also recently been detected in cocaine and counterfeit opioid and benzodiazepine pills (Carroll, Marshall, Rich, \& Green, 2017; Ciccarone, Ondocsin, \& Mars, 2017; Korte, 2018; Suzuki \& El-Haddad, 2017). Due to its lipophilic properties, fentanyl rapidly crosses the blood-brain barrier and binds to opioid receptors (Suzuki \& El-Haddad, 2017). Estimated to be between 30 to 50 times more potent than heroin and 50 to 100 times more potent than morphine, fentanyl poses a much higher risk of overdose, even to those exposed to very small quantities (Ciccarone et al., 2017; Suzuki \& El-Haddad, 2017).

In response to the worsening overdose crisis, policymakers and public health and medical institutions have launched initiatives to increase awareness of the risk and ubiquity of illicitly manufactured fentanyl in the community (U.S. Drug Overdose Deaths Continue to Rise; Increase Fueled by Synthetic Opioids, 2019). These efforts have primarily focused on promoting rigorously tested harm reduction measures, including education, naloxone distribution and access to low-barrier medication for opioid use disorder (MOUD) (Facing Addiction in America: The Surgeon General's Spotlight on Opioids, 2019). Naloxone is a fast-acting opioid antagonist that blocks the effects of opioids and can thus reverse opioid overdose. While the number of MOUD programs increase, and access to naloxone continues to expand in the United States to include first responders, lay people, and individuals who are at risk for overdose in the community, to date these efforts have been limited in correctional facilities (Horton et al., 2017; Kim, Irwin, \& Khoshnood, 2009; Wenger et al., 2019).

Correctional systems utilize intense surveillance, sanction and control to prevent illicit substances from entering into facilities (Kolind \& Duke, 2016). Despite these efforts, nearly all correctional facilities have ongoing problems with contraband, ranging from cell phones to illicit substances (Kolind \& Duke, 2016). Illicit fentanyl is inexpensive, widely available, and easy to smuggle into facilities to due to its high potency and need for only very small amounts (Increases in Fentanyl Drug Confiscations and Fentanyl-Related Overdose Fatalities, 2018; O'Donnell et al., 2017; Ostling et al., 2018; Reported Law Enforcement Encounters Testing Positive for Fentanyl Increase Across US | Drug Overdose | CDC Injury Center, 2019;U.S. Drug Overdose Deaths Continue to Rise; Increase Fueled by Synthetic Opioids, 2019). People who are incarcerated are at an increased risk of overdose when exposed to fentanyl, due to its high potency and the lower tolerance levels resulting from decreased opioid use while incarcerated.

\section{The present study}

There are many causes of mortality in incarcerated populations including fatal drug overdose risk immediately following release, natural deaths, and intentional deaths during incarceration, including suicide on-site (Arfken, Suchanek, \& Greenwald, 2017; Fazel \& Benning, 2006; Kim et al., 2007; Larney, Topp, Indig, O’Driscoll, \& Greenberg, 2012; Larney et al., 2014; Larney \& Farrell, 2017; Mumola, n.d.; Salive, Smith, \& Brewer, 1990). However, few studies have explored fentanyl-related overdose events in jails and prisons (Larney et al., 2014). Given the current fentanyl-driven overdose epidemic in the community and the presence of contraband drugs in correctional facilities, it is likely that there are fentanylrelated overdose deaths among individuals who are incarcerated. To better understand this, we conducted a comprehensive review of published reports of fentanylrelated overdose in correctional facilities, including jails and prisons. We aim to use our findings to gain a better understanding of the prevalence of fentanyl overdoses in prisons and jails in the United States to ultimately to reduce those overdoses and deaths.

\section{Methods}

In this comprehensive review, we examined fentanylrelated overdose events during incarceration in a jail or prison. We defined a fentanyl-related overdose event as the occurrence of at least one fentanyl-related overdose on a given day at a correctional facility. Thus, one overdose event may involve multiple overdose victims. Fentanyl-related overdoses that occurred at the same correctional facility but on separate days were not defined as one overdose event; rather overdoses on each individual day comprised unique events. We defined a fentanyl-related overdose as a fatal or non-fatal overdose that was either confirmed or suspected to involve fentanyl, as stated by the source.

We systematically reviewed the medical literature for reports of fentanyl-related overdose events during incarceration from January 1, 2013 to March 30, 2021. PubMed and PsycINFO were used to identify reports in the medical literature. We reviewed articles published using the search terms: ("fentanyl overdose") AND (prison OR jail).

Due to the fact that we found no cases in the peerreview literature, we expanded our search to include the lay press. Google search engine and Google alerts were used to identify cases of overdose in the media and lay press from January 1, 2013 to March 30, 2021. We used the same search terms, "fentanyl overdose in prison" and 
"fentanyl overdose in jail," in the Google search engine. Our results yielded local and national news articles, blogs, and press releases. All results were manually reviewed and examined until we reached a full page of search results that contained no articles relevant to the review. For each reported fentanyl overdose event identified, an additional Google search was initiated using details of the event as search terms, such as the name of the correctional facility or the overdose victim. All relevant articles and details of the overdose events were cataloged and collated.

\section{Results}

Not a single instance of fentanyl-related overdose reports or scientific articles among incarcerated individuals was identified through PubMed or PsycINFO. Our media analysis and search of articles in the lay press returned 113 relevant reports. After duplicate reports were combined, our results identified a total of 90 reported events comprising 179 fentanyl-related overdoses during the study period. Of these 179 fentanyl-related overdoses, 76 were fatal and 103 were nonfatal. One victim overdosed twice on different days (Hopkins, 2017). All United States regions were represented; specifically, reported overdose events occurred across 32 states and the District of Columbia (DC). California, Florida, Pennsylvania and Ohio were overrepresented with a total of $40,18,11$, and 10 overdoses, respectively. Of note, 13 of the 40 overdoses in California resulted from a single events at the Mule Creek State Prison in April 2018 (Goldberg, 2018). Based on the U.S. Department of Agriculture's Rural-Urban classification scheme (USDA ERS - Rural-Urban Continuum Codes, n.d.), 72 overdose events occurred in metropolitan counties, 17 events occurred in nonmetropolitan countries with urban populations, and 1 event occurred in Washington, DC. Characteristics of the known and suspected fentanyl overdose cases among incarcerated individuals are presented in Table 1.

Table 2 presents the breakdown of fatal and non-fatal overdoses in prisons and jails, and Fig. 1 presents overdoses in correctional settings over time.

\section{Confirmation of fentanyl}

In $77 \%(n=70)$ of included events, the involvement of fentanyl or its analogs was reported by the source. However, only a few overdose events $(n=12)$ were reported to include a systematic toxicology screening upon overdose. Most articles did not specify whether exposure to fentanyl was intentional or unintentional. During an overdose event in Covington, Kentucky on September 4, 2016, a young woman at the Kenton County Jail unintentionally consumed fentanyl and died of a fatal overdose (Crittenden Woman Sentenced to 224 Months for
Distribution of Drugs Resulting in Death, 2016). Toxicology reports revealed a mixture of fentanyl and morphine in her body at the time of death; however, both her mother-who delivered the substance through two individuals who were incarcerated at the jail-and the individual her mother purchased the substance from believed it to be heroin (Crittenden Woman Sentenced to 224 Months for Distribution of Drugs Resulting in Death, 2016).

\section{Fentanyl entrance}

In outlining the circumstances around the fentanylrelated overdose events, 33 (37\%) reports also described how fentanyl entered the correctional facility. Purported modes of entry included being smuggled in by a family member, a food service employee, a visitor during an open house, and an individual who was incarcerated and hid a bag of fentanyl inside her body. Many of the reports in the lay press emphasized the tight surveillance and security measures within correctional settings.

\section{Response to overdose}

Naloxone was administered to overdose victims in 20 (22\%) events, one of which occurred in 2015 and the remainder of which occurred between 2017 and 2021 . While naloxone was administered either by correctional or medical staff, individuals who were incarcerated played a critical role in response to overdoses in a couple of instances, such as when they notified correctional staff at the Lorain County Jail in Elyria, Ohio about an individual who was incarcerated who was overdosing (Sandy, 2016). In another instance from May 2014, individuals who were incarcerated at the Henrico County Jail in Henrico, Virginia applied ice on parts of the victim's body in attempts to revive him after he overdosed, which is an ineffective method to reverse opioid overdose (McKelway, 2015). The overdose accounts included in this review demonstrate how the onset of fentanyl-related overdose symptoms is rapid. In an article describing a fatal overdose at the Baltimore Central Booking and Intake Center in June 2018, a victim's health is described as having deteriorated rapidly after ingesting what was later confirmed to be a mixture of morphine and fentanyl. Less than an hour prior to overdosing, he was described as "cool, calm, relaxed" (Bogel-Burroughs, 2018). In another fatal overdose case, an individual who was incarcerated died on June 28, 2015 while in police custody at the Gunnison County Jail in Gunnison, Colorado. A check performed at 9:01 am did not raise concerns about his health. However, he was found unconscious 3 minutes later (Michell, 2016). 
Table 1 Date, location, circumstances of fentanyl-related overdose incidents, United States, 2013-March 2021

\begin{tabular}{|c|c|c|c|c|c|c|c|}
\hline Date & State & Facility & Fatal & Nonfatal & $\begin{array}{l}\text { Fentanyl } \\
\text { Confirmed }\end{array}$ & $\begin{array}{l}\text { Mode of } \\
\text { Entry }\end{array}$ & Naloxone \\
\hline 2013 (Fairbanks, 2016) & NY & Attica Correctional Facility & 3 & 0 & Yes & Yes & No \\
\hline May 2014 (McKelway, 2015) & VA & Henrico County Jail & 1 & 0 & Yes & Yes & No \\
\hline May 2014 (Doug Rogers, 2015) & PA & Erie County Prison & 1 & 3 & Yes & Yes & No \\
\hline $\begin{array}{l}\text { May } 2015 \text { (Woman died of fentanyl } \\
\text { overdose at Cook County Jail: Autopsy, 2019) }\end{array}$ & OR & $\begin{array}{l}\text { Multnomah County Detention Center } \\
\text { (Justice Center) }\end{array}$ & 0 & 3 & Yes & Yes & No \\
\hline June 2015(Mitchell, 2018) & $\mathrm{CO}$ & Gunnison County Jail & 1 & 0 & Yes & No & No \\
\hline July 2015 (Denson, n.d.) & ME & York County Jail & 0 & 3 & No & No & No \\
\hline Oct 2015 (Sturgeon, 2015) & NJ & Bayside State Prison & 0 & 1 & Yes & Yes & Yes \\
\hline Mar 2016 (Sandy, 2016) & $\mathrm{OH}$ & Lorain County Jail & 1 & 0 & Yes & No & No \\
\hline Mar 2016 (Corwin, 2016) & $\mathrm{NH}$ & $\begin{array}{l}\text { Hillsborough County Department of } \\
\text { Corrections }\end{array}$ & 1 & 0 & Yes & No & No \\
\hline Apr 2016 (Dolan, n.d.) & ME & Cumberland County Jail & 1 & 0 & Yes & No & No \\
\hline $\begin{array}{l}\text { Sept } 2016 \text { (Crittenden Woman Sentenced } \\
\text { to } 224 \text { Months for Distribution of Drugs } \\
\text { Resulting in Death, 2016) }\end{array}$ & KY & Kenton County Jail & 1 & 0 & Yes & Yes & No \\
\hline Nov 2016 (Schaefer, 2016) & $\mathrm{OH}$ & Montgomery County Jail & 1 & 0 & Yes & Yes & No \\
\hline Dec 2016 (Treleven, 2020) & WI & Dane County Jail & 1 & 0 & Yes & No & No \\
\hline Jan 2017 (Berg, 2019) & Ml & Lakeland Correctional Facility & 1 & 2 & No & Yes & No \\
\hline May 2017 (Harlow, 2017) & ME & Somerset County Jail & 0 & 1 & No & No & Yes \\
\hline May 2017 (Alexander, 2017) & D.C. & D.C. Jails & 2 & 0 & Yes & No & No \\
\hline July 2017 (Loannou, 2017) & CA & Santa Clara County Main Jail & 0 & 4 & No & No & No \\
\hline $\begin{array}{l}\text { July } 2017 \text { (Coroner: LaPorte County Jail } \\
\text { Inmate Died by Accidental Overdose, 2017) }\end{array}$ & IN & LaPorte County Jail & 1 & 0 & Yes & No & No \\
\hline Oct 2017 (Burger, 2017) & $\mathrm{OH}$ & Franklin County Jail & 1 & 0 & Yes & No & No \\
\hline Oct 2017 (Hopkins, 2017) & AK & Hiland Mountain Correctional Center & 0 & 5 & Yes & Yes & Yes \\
\hline Nov 2017 (Craig, 2019) & NY & Livingston County Jail & 1 & 0 & Yes & Yes & No \\
\hline Nov 2017 (Ward, n.d.) & KY & Montgomery County Regional Jail & 1 & 0 & Yes & Yes & No \\
\hline Dec 2017(Ovalle, 2017) & $\mathrm{FL}$ & Miami-Dade Jail & 2 & 0 & No & No & No \\
\hline Jan 2018 (Naylor, 2018) & PA & Cumberland County Prison & 1 & 0 & Yes & Yes & No \\
\hline Feb 2018 (Bustos, 2018) & $\mathrm{FL}$ & Venice Police Department & 1 & 0 & Yes & No & No \\
\hline Apr 2018 (Stucker, 2019) & $\mathrm{NH}$ & Strafford County House of Corrections & 1 & 0 & Yes & Yes & No \\
\hline Apr 2018 (Mitchell, 2018) & $\mathrm{TN}$ & Sumner County Jail & 0 & 6 & No & Yes & No \\
\hline Apr 2018 (Goldberg, 2018) & CA & Mule Creek State Prison & 1 & 12 & Yes & No & No \\
\hline May 2018 (Burns, 2018) & NC & Durham County Jail & 1 & 0 & Yes & No & No \\
\hline May 2018 (Broden, 2018) & TN & Rutherford County Jail & 0 & 1 & Yes & Yes & Yes \\
\hline June 2018(Bogel-Burroughs, 2018) & MD & $\begin{array}{l}\text { Baltimore Central Booking and Intake } \\
\text { Center }\end{array}$ & 1 & 0 & Yes & No & No \\
\hline June 2018 (Jane Wester \& Kane, 2018) & NC & Mecklenburg County Jail & 1 & 0 & Yes & No & No \\
\hline July 2018 (Wester, n.d.) & NC & Mecklenburg County Jail & 1 & 0 & Yes & No & No \\
\hline Aug 2018(Lisenby, 2018) & $\mathrm{MO}$ & St. Louis Medium Security Institution & 1 & 0 & Yes & No & No \\
\hline Aug 2018 (Brookbank, 2019) & $\mathrm{OH}$ & Ross Correctional Institution & 0 & 2 & Yes & No & No \\
\hline Sept 2018 (Miller, 2018) $^{R}$ & $\mathrm{FL}$ & Marion County Jail & 1 & 0 & Yes & Yes & No \\
\hline Nov 2018 (Signorini, 2019) & PA & Allegheny County Jail & 1 & 0 & Yes & No & No \\
\hline Nov 2018 (Perlstein, 2019) & LA & Orleans Justice Center & 1 & 0 & Yes & No & No \\
\hline $\begin{array}{l}\text { Dec } 2018^{\mathrm{D}} \text { (Drug may be to blame for } \\
\text { Albany County inmate's death, n.d.) }\end{array}$ & NY & Albany County Jail & 1 & 0 & Yes & Yes & No \\
\hline
\end{tabular}


Table 1 Date, location, circumstances of fentanyl-related overdose incidents, United States, 2013-March 2021 (Continued)

\begin{tabular}{l} 
Date \\
\hline Dec 2018 (Klein, 2018) \\
Dec 2018 (Sutyak, 2018) \\
Dec 2018 (Murphy, n.d.) \\
Jan 2019 (Jail Sweep Underway after \\
Pasco Inmate Dies from Drug Overdose, \\
2019) \\
Jan 2019 (Pasco Man Pleads Guilty To \\
Causing Series Of Overdoses While \\
Incarcerated At The Pasco County Jail, \\
2019) \\
Jan 2019 (Deike, 2019)
\end{tabular}

Feb 2019 (Pasco County man responsible for numerous overdoses at Pasco County jail sentenced to 27 years in federal prison, 2020)

Mar 2019 (Woman died of fentanyl overdose at Cook County Jail: Autopsy, 2019)

Mar 2019 (WKBN Staff, 2019)

Mar 2019 (Rains, 2019)

Mar 2019 (Schwigert, 2019)

Apr 2019 (Owens, 2019)

Apr 2019 (J Wester, 2019)

Apr 2019 (3 Inmates Connected to Jail Overdoses, 2019)

Apr 2019 (Goodrich, 2019)

May 2019 (City News Services, 2019)

May 2019 (Dave Rogers, 2019)

May 2019 (Robert Patrick, 2019; Roberts Patrick, 2020)

June 2019 (Smay, 2019)

July 2019 (Berstein, 2020)

July 2019 (City News Services, 2019)

Aug 2019 (Ferrise, 2019)

Aug 2019 (Associated Press, 2019b)

Sept 2019 (Harris, 2019)

Oct 2019 (Barbra, 2019)

Oct 2019 (Poli, n.d.)

Oct 2019 (Associated Press, 2019a)

Nov 2019 (Dickson, n.d.)

Jan 2020 (McDonald, 2020)

Feb 2020 (Schmidt, 2020)

Feb 2020 (Associated Press, 2020a)

Mar 2020 (Winston, 2020)

Apr 2020 (Lubinski, 2020)

May 2020 (Camden County Jail Inmate Admits Providing Drugs That Caused Fellow Inmate's Overdose Death, 2021)
State Facility

KY Boyd County Jail

$\mathrm{OH} \quad$ Portage County Jail

NY Nassau County Jail

FL Land O' Lakes Detention Center

FL Pasco County Jail

$\mathrm{OH} \quad$ Cuyahoga County Jail

FL Pasco County Jail

IL Cook County Jail

PA

$\mathrm{C}$

$\mathrm{NC}$ $A Z$

MN Blue Earth County Jail

CA $M A$

MO St. Charles County Jail

WA Spokane County Jail

OR Multnomah County Jail

CA San Diego Central Jail

$\mathrm{OH} \quad$ Cuyahoga County Jail

MO St. Louis Medium Security Institution

FL Columbia Correctional Institution 2

CA San Francisco County Jail $\quad 0 \quad 5$

$\mathrm{OH} \quad$ Franklin County Jail

MO Moberly Correctional Center

MI Women's Huron Valley Correctional Facility

CA San Diego Central Jail $\quad 1 \quad 0 \quad$ Yes No No

IL Madison County Jail $\quad 0 \quad 3 \quad$ Yes

PA Curran-Fromhold Correctional Facility $3 \quad 1 \quad$ Yes

FL Palm Beach County Jail $\quad 1 \quad 0 \quad$ Yes

MO Clay County Detention Center $\quad 1 \quad 6 \quad$ No

GA

Camden County Detention Facility

Confirmed Entry

No Yes

Yes

Yes

No

No

Yes

Yes

Yes

No

No

No

Yes

es


Table 1 Date, location, circumstances of fentanyl-related overdose incidents, United States, 2013-March 2021 (Continued)

\begin{tabular}{|c|c|c|c|c|c|c|c|}
\hline Date & State & Facility & Fatal & Nonfatal & $\begin{array}{l}\text { Fentanyl } \\
\text { Confirmed }\end{array}$ & $\begin{array}{l}\text { Mode of } \\
\text { Entry }\end{array}$ & Naloxone \\
\hline June 2020 (Finn, 2020) & NY & Yaphank Facility & 0 & 1 & No & No & No \\
\hline June 2020 (Finn, 2020) & NY & Riverhead Jail & 0 & 5 & No & No & No \\
\hline June 2020 (Sledge, 2020) & LA & New Orleans Jail & 1 & 0 & Yes & No & No \\
\hline July 2020 (Craig, 2020) & $\mathrm{Ml}$ & Michigan Department of Corrections & 1 & 0 & No & No & No \\
\hline $\begin{array}{l}\text { Aug } 2020 \text { (Coroner: Overdose Caused } \\
\text { Iroquois Co. Inmate's Death, 2020; } \\
\text { Iroquois County Inmate Died of Fentanyl, } \\
\text { Heroin Overdose, 2020) }\end{array}$ & IL & Iroquois County Jail & 2 & 0 & Yes & No & No \\
\hline Aug 2020 (Gartrell, 2020) & CA & Contra Costa Jail & 1 & 0 & Yes & No & No \\
\hline Aug 2020 (Hlavaty, 2021)) & $\mathrm{OH}$ & Cuyahoga County Jail & 1 & 0 & Yes & Yes & No \\
\hline $\begin{array}{l}\text { Sep } 2020 \text { (Minneapolis Man Charged } \\
\text { With Smuggling Heroin Into Hennepin } \\
\text { County Jail, n.d.; } \\
\text { Nelson, 2020, p. 3) }\end{array}$ & $\mathrm{MN}$ & Hennepin County Jail & 0 & 3 & No & Yes & Yes \\
\hline $\begin{array}{l}\text { Sep } 2020 \text { (Associated Press, 2020b; } \\
\text { Schafer, 2020) }\end{array}$ & Wl & Manitowoc County Jail & 1 & 0 & Yes & Yes & No \\
\hline Oct 2020 (Ireland, 2020) & CA & Vista Detention Facility & 1 & 0 & Yes & No & No \\
\hline Nov 2020 (Ireland, 2021; Riggins, 2021) & CA & Otay Mesa Jail & 1 & 0 & Yes & No & No \\
\hline Dec 2020 (WDTV News Staff, 2020) & WV & North Central Regional Jail & 2 & 1 & No & No & No \\
\hline Dec 2020 (Saunders, 2020) & CA & San Diego Central Jail & 0 & 6 & No & No & Yes \\
\hline Dec 2020 (Kemp, n.d.; Lee, 2020) & CA & Mendocino County Jail & 0 & 2 & No & No & Yes \\
\hline Jan 2021 (Nuttle, 2021; Stanton, 2021) & CA & Sacramento County Jail & 0 & 4 & No & Yes & Yes \\
\hline Feb 2021 (Gottlieb, 2021) & WA & Clallam County Correctional Facility & 0 & 1 & Yes & Yes & Yes \\
\hline $\begin{array}{l}\text { Mar } 2021 \text { (Sheriff's Office Conducts Drug } \\
\text { Search in Jail After Drug Overdose, n.d.) }\end{array}$ & NC & Bladen County Detention Facility & 0 & 1 & No & No & No \\
\hline
\end{tabular}

\section{Discussion}

This is the first paper to summarize fentanyl-related overdose events that occurred during incarceration. No reports were identified in the medical literature. However, we identified 90 overdose events totaling 179 overdoses in the lay press and these reports are rapidly increasing. The large discrepancies in reporting between the lay press and the medical literature suggests underreporting of overdose events in prisons and jails, and a lack of attention given to the opioid crisis in correctional settings more generally. The number of fentanyl overdoses is likely much higher, as in an article published in the Orange County Register, a sheriff reported that 129 doses of naloxone had been administered to 70 individuals in 2019 (Saavedra, 2020), and yet, our media search revealed only a single reported overdose event in Orange

Table 2 Number of reported fatal and nonfatal overdoses by facility type (prison or jail)

\begin{tabular}{lll}
\hline & Fatal Overdoses & Nonfatal Overdoes \\
\hline Prison & 15 & 26 \\
Jail & 61 & 77 \\
Total & 76 & 103 \\
\hline
\end{tabular}

County that year (OC Inmate's Death Caused By Fentanyl Overdose, Officials Say, 2020). This suggests a vast under reporting of overdoses, and likely fentanyl overdoses in prisons and jails. We suspect that correctional administrators endure tremendous pressure to minimize the prevalence of substances and contraband inside, in an effort to maintain the perception that jails are safe and rehabilitative. For example, our team is anecdotally aware of six events of fentanyl related overdoses and deaths, that occurred in correctional facilities in two different states where the attending clinicians were told by their superiors not to report these cases in the medical literature.

As fentanyl contamination of the drug supply continues in the community, we expect its presence in correctional facilities to likewise rise in parallel. However, the scope of the problem is unclear because fentanyl overdoses in correctional facilities are not being systematically tracked. Unfortunately, as demonstrated by the few reports of systematic toxicology screening in our study, there currently is no standard of care for evaluating deaths among people who were incarcerated; ideally, an autopsy and complete toxicologic screening should be completed for all deaths occurring in correctional 


\section{Number of Reported Overdoses by Year}

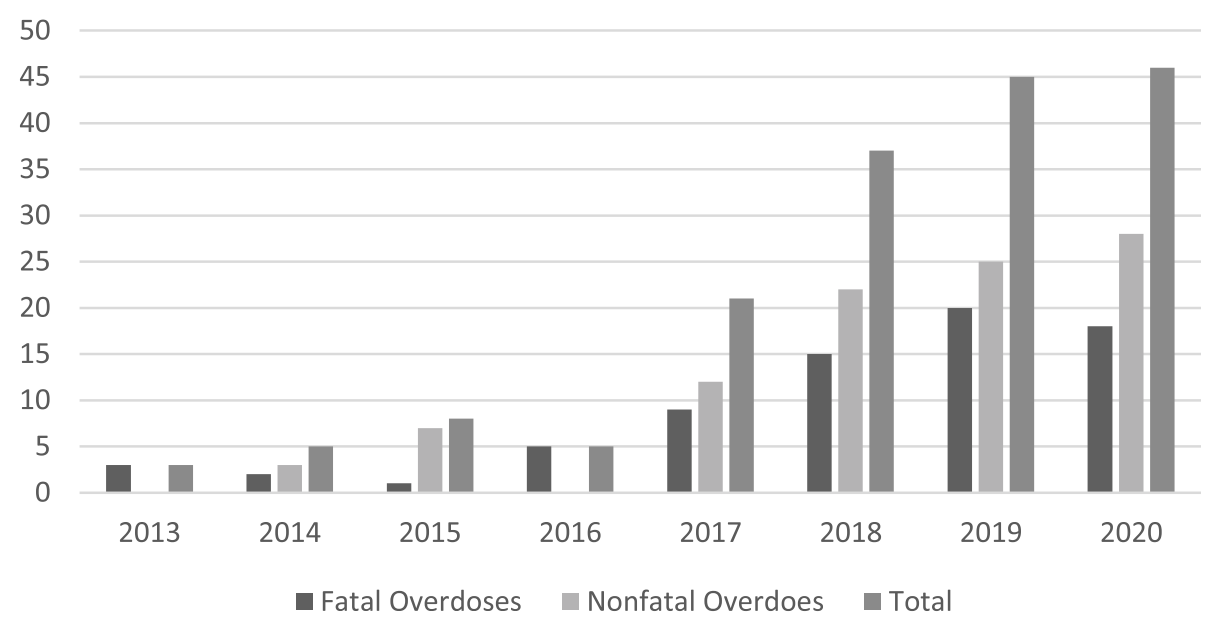

Fig. 1 Number of reported overdoses by year (2013-2020)

facilities. Enforcing a standard of care for all deaths and a system to systematically track deaths in correctional settings is essential to fully understanding the scope of the crisis.

However, further data is not necessary to begin addressing overdoses and deaths in corrections. Three evidence-based interventions can, and must, be implemented 1) educate correctional staff and individuals who are incarcerated about the risks of fentanyl, 2) ensure widespread, readily available naloxone accompanied with training on how to properly administer it, and 3) expand availability of medications for opioid use disorder in prisons and jails.

Our study found that naloxone was reported to be administered in only $22 \%$ of included overdose events. Both correctional staff and individuals who are incarcerated should be educated on the growing prominence of fentanyl, its effects, signs of an opioid overdose, and the use of naloxone. As a harm reduction measure, naloxone trainings should be widely available to all staff and individuals who are incarcerated. Studies of naloxone training in the correctional setting underscore the potential for individuals who are incarcerated to participate in trainings and correctly administer intranasal naloxone while incarcerated (Green, Ray, Bowman, McKenzie, \& Rich, 2014; Kobayashi et al., 2017; Parmar, Strang, Choo, Meade, \& Bird, 2017; Petterson \& Madah-Amiri, 2017). At a minimum, naloxone should be present in all correctional units, and units should be staffed with correctional officers who are trained in naloxone administration. As of November 2018, RIDOC implemented the first statewide naloxone training for correctional officers, which included trainings to recognize overdose symptoms and correctly administer naloxone. Naloxone is now offered to RIDOC officers who completed the training and is readily available in all Rhode Island prisons (personal communication Jennifer Clarke, MD, MPH).

In addition to naloxone distribution, MOUD remain the gold-standard of treatment for OUD and an effective harm-reduction intervention to prevent overdose (Facing Addiction in America: The Surgeon General's Spotlight on Opioids, 2019). The availability of and attitudes toward MOUD in correctional facilities are rapidly changing given the magnitude of the epidemic and the demonstrated decrease in overdose deaths among individuals recently released from incarceration. In a randomized clinical trial conducted by Kinlock and Gordon et al. in Baltimore, Maryland, participants who were incarcerated and assigned to receive both counseling and methadone were less likely to test positive for opioids at one-, three-, six-, and twelve-month follow-ups in the community compared to those who received only counseling (Kinlock et al., 2007; Kinlock, Gordon, Schwartz, Fitzgerald, \& O'Grady, 2009; Kinlock, Gordon, Schwartz, \& O'Grady, 2008). Our team has also demonstrated that individuals who are maintained on methadone while incarcerated are more likely to return to their methadone clinic after they are released than those who undergo forced withdrawal while incarcerated (Rich et al., 2015). Thus, not only does providing access to MOUD in corrections increase individual's chance of recovery upon reentry, it also reduces risk of overdose during and after incarceration. Despite the robust literature demonstrating its efficacy, the use of MOUD in correctional facilities is still met with resistance. According to the Jail and Prison Opioid Project (JPOP), only 356 correctional facilities out of the nearly 5000 facilities in the United States offer any form of MOUD to individual who are 
incarcerated (Prison Opioid Project - Medication for Opioid Use Disorder and the Criminal Justice System, n.d.).The compounded problem of extremely concentrated, widely available and affordable fentanyl, and the lowered tolerance of individuals during incarceration, necessitates evidence-based interventions. Generally, there has been a lack of response among correctional facilities to address the growing opioid crisis; our study found that among the facilities that have attempted to respond to the overdose crisis, they have predominantly done so through increasing security and surveillance. However, a recent study found that increased surveillance and punishment among people using opioids was correlated to less likelihood to seek treatment and begin recovery (Mazhnaya et al., 2016). Harm-reduction interventions in the community have effectively reduced risk of overdose; however, there has been little focus on promoting these in criminal justice settings as well.

Our findings should be interpreted in light of several limitations. To our knowledge, no scientific papers about fentanyl overdose during incarceration have been published, and cases reported in the lay press likely represent only a fraction of all overdose events. Moreover, due to the 2019 novel coronavirus (COVID-19) pandemic, media coverage on correctional facilities has likely shifted towards COVID-19 outbreaks in facilities and away from fentanyl-related overdoses. Reluctance to release data on overdose within corrections likely also results in the underreporting of fentanyl-related overdoses. More systematic data collection, reporting, and surveillance of unintentional drug-induced deaths is needed to understand the magnitude of fatal and nonfatal fentanyl-related overdoses in the incarcerated population.

\section{Conclusions}

Fentanyl-related overdoses in correctional facilities are likely spill-over from the opioid epidemic in the community. Fear and misinformation around fentanyl exposure have contributed to the stigmatization of OUD and resistance towards effective harm reduction measures and treatment. Illicit drug use in correctional facilities occurs regularly. In the face of this evolving fentanyl-driven opioid epidemic, correctional staff, individuals who are incarcerated, and the public must be equipped with the knowledge and tools necessary to reduce and prevent fatal and nonfatal overdose events. Naloxone and MOUD, specifically, are beneficial after release and should also be safe and effective in jails and prisons. Moreover, systematic data collection, including toxicology screens, and increased reporting of fatalities in corrections are urgently needed to monitor and curb the opioid overdose epidemic.

\section{Author details}

${ }^{1}$ The Center for Health and Justice Transformation, The Miriam Hospital, Providence, RI, USA. ${ }^{2}$ Center of Biomedical Research Excellence on Opioids and Overdose, The Rhode Island Hospital, RI, Providence, USA. ${ }^{3}$ Department of Mental Health, Johns Hopkins Bloomberg School of Public Health, Baltimore, MD, USA. ${ }^{4}$ Department of Epidemiology, Brown University School of Public Health, Providence, RI, USA. 'Division of General Internal Medicine, Albert Einstein College of Medicine, New York City, NY, USA. ${ }^{6}$ Department of Social Medicine, University of North Carolina, Chapel Hill, NC, USA. ${ }^{7}$ Christiana Care Health System, Newark, DE, USA. ${ }^{8}$ The Heller School of Social Policy and Management, Brandeis University, Waltham, MA, USA. 'Department of Emergency Medicine, Brown School of Medicine, RI, Providence, USA.

${ }^{10}$ Rhode Island Department of Health, Providence, RI, USA.

Received: 16 July 2020 Accepted: 5 May 2021

Published online: 19 May 2021

\section{References}

3 inmates connected to jail overdoses. (2019, May 15). Kingman Daily Miner. https://kdminer.com/news/2019/may/15/3-inmates-connected-jail-overdoses/ Alexander, K. L. (2017, June 20). Two D.C. jail inmates found dead in May died from opioid overdoses. Washington Post. https://www.washingtonpost.com/ local/public-safety/two-dc-jail-inmates-found-dead-in-may-died-from-opioidoverdoses/2017/06/20/b2085796-55fa-11e7-a204-ad706461fa4f_story.html

Arfken, C. L., Suchanek, J., \& Greenwald, M. K. (2017). Characterizing fentanyl use in methadone-maintained clients. Journal of Substance Abuse Treatment, 75, 17-21. https://doi.org/10.1016/j.jsat.2017.01.004.

Associated Press. (2019a). Autopsy: 2 Moberly Inmates Died From Overdose Deaths. US News \& World Report. //www.usnews.com/news/best-states/missouri/a rticles/2019-12-05/autopsy-2-moberly-inmates-died-from-overdose-deaths

Associated Press. (2019b). Inmate's Death at St. Louis Jail Blamed on Fentanyl Overdose. US News \& World Report. https://www.usnews.com/news/best-sta tes/missouri/articles/2019-10-18/inmates-death-at-st-louis-jail-blamed-onfentanyl-overdose

Associated Press. (2020a, March 5). 3 inmates in Philadelphia die of fentanyl overdose; jail investigating [Text.Article]. Fox29; FOX 29 news Philadelphia. https://www.fox29.com/news/3-inmates-in-philadelphia-die-of-fentanyloverdose-jail-investigating

Associated Press. (2020b, December 2). Manitowoc co. Jail inmate dies of fentanyl overdose, charges recommended. https:/www.nbc15.com/2020/12/ 02/manitowoc-co-jail-inmate-dies-of-fentanyl-overdose-chargesrecommended/

Barbra, M. (2019, October 8). Fentanyl scare sends 9 deputies, 5 inmates to hospital. The San Francisco Examiner. https://www.sfexaminer.com/news/na rcotic-exposure-at-sf-county-jail-sends-5-deputies-5-inmates-to-hospital/

Berg, K. (2019, October 9). Lawsuit: Charlotte man died of overdose from prison drug smuggling ring. Lansing State Journal. https://www.lansingstatejournal. com/story/news/2019/12/09/lawsuit-charlotte-man-died-overdose-prisondrug-smuggling-ring/4351994002/

Berstein, M. (2020, September 30). \$10 million lawsuit filed against Multnomah County in 2019 drug overdose death of inmate. Oregonlive. https://www. oregonlive.com/crime/2020/09/10-million-civil-rights-suit-filed-againstmultnomah-county-stemming-from-2019-death-of-inmate-who-died-fromdrug-overdose-in-custody.html

Binswanger, I. A., Stern, M. F., Deyo, R. A., Heagerty, P. J., Cheadle, A., Elmore, J. G., $\&$ Koepsell, T. D. (2007). Release from prison-A high risk of death for former inmates. New England Journal of Medicine, 356(2), 157-165. https://doi.org/1 $0.1056 /$ NEJMsa064115.

Binswanger, I. A., Stern, M. F., Yamashita, T. E., Mueller, S. R., Baggett, T. P., \& Blatchford, P. J. (2016). Clinical risk factors for death after release from prison in Washington state: A nested case-control study. Addiction (Abingdon, England), 111(3), 499-510. https://doi.org/10.1111/add.13200.

Bogel-Burroughs, N. (2018, August 8). Disabled man who died in Baltimore jail overdosed on morphine and fentanyl; advocates ask why he was there. The Baltimore Sun. https://www.baltimoresun.com/news/crime/bs-md-ci-jail-dea th-autopsy-20180808-story.html

Boutwell, A. E., Nijhawan, A., Zaller, N., \& Rich, J. D. (2007). Arrested on heroin: A national opportunity. Journal of Opioid Management, 3(6), 328-332. https:// doi.org/10.5055/jom.2007.0021.

Brinkley-Rubinstein, L., Macmadu, A., Marshall, B. D. L., Heise, A., Ranapurwala, S. I., Rich, J. D., \& Green, T. C. (2018). Risk of fentanyl-involved overdose among 
those with past year incarceration: Findings from a recent outbreak in 2014 and 2015. Drug and Alcohol Dependence, 185, 189-191. https://doi.org/10.101 6/j.drugalcdep.2017.12.014.

Broden, S. (2018). Inmate overdoses while Rutherford County jail waits on contraband scanner arrival. The Daily News Journal. https://www.dnj.com/ story/news/2018/07/09/inmate-overdose-sparks-rutherford-sheriff-seek-sca nner-detect-drug-smuggling/767558002/

Brookbank, S. (2019, August 30). Ross overdose: Heroin-fentanyl mix sickened 29 at prison. https://www.cincinnati.com/story/news/2018/08/30/ross-overdoseheroin-fentanyl-mix-sickened-29-prison/1142138002/

Burger, B. (2017, December 8). Coroner determines jail inmate died of fentanyl overdose. The Columbus Dispatch. https://www.dispatch.com/news/201712 08/coroner-determines-jail-inmate-died-of-fentanyl-overdose

Burns, M. (2018, July 19). Autopsy: Durham inmate died of drug overdose: WRAL. Com. https://www.wral.com/autopsy-durham-inmate-died-of-drugoverdose/17708319/

Bustos, J. (2018, February 22). Man dies while in custody of Venice IL police Belleville news-democrat. Belleville News-Democrat. https://www.bnd.com/ news/local/article201620669.html

Camden County jail inmate admits providing drugs that caused fellow inmate's overdose death. (2021, March 2). The United States Department of Justice, U. S. Attorney's Office. https://www.justice.gov/usao-sdga/pr/camden-county-ja il-inmate-admits-providing-drugs-caused-fellow-inmates-overdose-death

Carroll, J. J., Marshall, B. D. L., Rich, J. D., \& Green, T. C. (2017). Exposure to fentanyl-contaminated heroin and overdose risk among illicit opioid users in Rhode Island: A mixed methods study. International Journal of Drug Policy, 46, 136-145. https://doi.org/10.1016/j.drugpo.2017.05.023.

Ciccarone, D., Ondocsin, J., \& Mars, S. G. (2017). Heroin uncertainties: Exploring users' perceptions of fentanyl-adulterated and -substituted 'heroin'. International Journal of Drug Policy, 46, 146-155. https://doi.org/10.1016/j. drugpo.2017.06.004

City News Services. (2019, October 29). 2 jail deaths blamed on drug overdoses. FOX 5 San Diego. https://fox5sandiego.com/news/2-jail-deaths-blamed-ondrug-overdoses/

Coroner: LaPorte County Jail inmate died by accidental overdose. (2017, August 9). https://www.wndu.com. https://www.wndu.com/content/news/CoronerLaPorte-County-Jail-inmate-died-by-accidental-overdose-439469063.html

Coroner: Overdose caused Iroquois Co. Inmate's death. (2020, September 29). WANDTV. https://www.wandtv.com/news/coroner-overdose-caused-iroquois-co-inma tes-death/article_36033fda-0290-11eb-bb09-27d2bd23d048.html

Corwin, E. (2016, April 20). Jailed homeless activist died of Fentanyl Overdose, Says Medical Examiner. NHPR. https://www.nhpr.org/post/jailed-homeless-a ctivist-died-fentanyl-overdose-says-medical-examiner

Craig. (2020, July 24). MSP investigating prison overdose death during ban on visitors due to coronavirus. WXYZ. https://www.wxyz.com/news/msp-investiga ting-prison-overdose-death-during-ban-on-visitors-due-to-coronavirus

Craig, G. (2019, February 8). Livingston County Sheriff's deputies sued over death of man who overdosed in jail. Democrat and Chronicle. https://www. democratandchronicle.com/story/news/2019/02/08/livingston-countysheriffs-deputies-sued-over-jail-overdose-death/2800291002/

Crittenden Woman Sentenced to 224 Months for Distribution of Drugs Resulting in Death. (2016, August 11). United States Department of Justice. https://www. justice.gov/usao-edky/pr/crittenden-woman-sentenced-224-monthsdistribution-drugs-resulting-death

Deike, J. (2019, January 23). Nurse attacked, narcotics seized at Cuyahoga County Jail as crisis deepens. https://www.cleveland19.com. https://www.cleveland19.com/2 019/01/23/nurse-strangled-narcotics-seized-cuyahoga-county-jail-crisis-deepens/

Denson, B. (n.d.). 3 OD on dangerous drug in Portland jail; feds say inmate smuggled contraband inside her body. The Oregonian. Retrieved April 12, 2021, from https://www.oregonlive.com/portland/2015/03/three_od_on_da ngerous_drug_smu.html

Dickson, J. D. (n.d.). November death of Michigan inmate, 37, was fentanyl overdose. The Detroit news. Retrieved March 16, 2021, from https://www. detroitnews.com/story/news/local/michigan/2020/03/03/november-deathmichigan-inmate-37-fentanyl-overdose/4940142002/

Dolan, S. (n.d.). Portland jail inmate's drug death classified as accidental. Press Herald Retrieved April 12, 2021, from https://www.pressherald.com/2016/05/ 09/portland-jail-inmates-drug-death-classified-as-accidental/.

Drug may be to blame for Albany County inmate's death. (n.d.). WNYT. Retrieved May 11, 2020, from https://wnyt.com/news/grey-death-rare-drug-albanycounty-jail/5189111
Facing Addiction in America: The Surgeon General's Spotlight on Opioids. (2019). National Intsitute of Health. https://www.drugabuse.gov/nidamed-medicalhealth-professionals/opioid-crisis-pain-management/facing-addiction-in-a merica-surgeon-generals-spotlight-opioids

Fairbanks, P. (2016, September 9). Attica heroin and fentanyl overdoses lead to prison sentences. The Buffalo News. https://buffalonews.com/news/local/ crime-and-courts/attica-heroin-and-fentanyl-overdoses-lead-to-prisonsentences/article aef38c12-cff5-5a9e-9942-ccbb47b45bc3.html

Fazel, S., \& Benning, R. (2006). Natural deaths in male prisoners: A 20-year mortality study. European Journal of Public Health, 16(4), 441-444. https://doi. org/10.1093/eurpub/cki223.

Ferrise, A. (2019, June 3). Cuyahoga County releases video of jail overdose death that led to warden and officer's indictment. Cleveland.Com. https://www. cleveland.com/metro/2019/06/cuyahoga-county-releases-video-of-jailoverdose-death-that-led-to-warden-and-officers-indictment.html

Finn, L. (2020, June 9). 6 Inmates Overdose On Drugs in County Jails: Officials. https://news.yahoo.com/6-inmates-overdose-drugs-county-225310068.html

Gartrell, N. (2020, September 23). Man died of drug overdose in contra Costa jail, coroner finds. Mercury News. https://www.mercurynews.com/2020/09/23/ma n-died-of-drug-overdose-in-contra-costa-jail-days-after-he-was-arrested-andbriefly-hospitalized/

Goldberg, T. (2018, May 1). Fentanyl blamed for apparent overdoses that killed California prisoner, sickened others | KQED. TQED. https://www.kqed.org/ news/1 1665693/fentanyl-blamed-for-apparent-overdoses-that-killed-californiaprisoner-sickened-others

Goodrich, K. (2019, April 4). Blue Earth County Jail inmate allegedly overdosed on fentanyl. The Free Press. https://www.mankatofreepress.com/news/local_ news/blue-earth-county-jail-inmate-allegedly-overdosed-on-fentanyl/a rticle_13d04a58-5728-11e9-83c8-5334a7016a71.html

Gottlieb, P. (2021, February 9). Clallam County inmate overdoses while in jail. https://www.sequimgazette.com/news/clallam-county-inmate-overdoseswhile-in-jail/

Green, T. C., Clarke, J., Brinkley-Rubinstein, L., Marshall, B. D. L., Alexander-Scott, N., Boss, R., \& Rich, J. D. (2018). Postincarceration fatal overdoses after implementing medications for addiction treatment in a statewide correctional system. JAMA Psychiatry, 75(4), 405-407. https://doi.org/10.1001/ jamapsychiatry.2017.4614

Green, T. C., Ray, M., Bowman, S. E., McKenzie, M., \& Rich, J. D. (2014). Two cases of intranasal naloxone self-administration in opioid overdose. Substance Abuse, 35(2), 129-132. https://doi.org/10.1080/08897077.2013.825691.

Harlow, D. (2017, May 5). Somerset County Jail inmate who overdosed saved by opioid antidote Narcan. Kennebec Journal and Morning Sentinel. https:// www.centralmaine.com/2017/05/05/inmate-at-the-somerset-county-jail-whooverdosed-saved-by-opioid-antidote-narcan/

Harris, J. (2019, December 3). Autopsy: Columbia County inmates died after exposure to fentanyl. News4jax. https://www.news4jax.com/news/2019/12/ 04/autopsy-columbia-county-inmates-died-after-exposure-to-fentanyl/

Hlavaty, K. (2021, January 21). Euclid man indicted for allegedly causing overdose death of cellmate in Cuyahoga County Jail. https://www.news5cleveland.com/ news/local-news/investigations/county-jail/euclid-man-indicted-for-allegedlycausing-overdose-death-of-cellmate-in-cuyahoga-county-jail

Hopkins, K. (2017, November 1). 5 Alaska inmates overdosed within 24 hours at Hiland prison, officials say. Alaskas News Sourse. https://www.alaska snewssource.com/content/news/5-Alaska-inmates-overdosed-within-24hours-at-Hiland-prison-officials-say-454543013.html

Horton, M., McDonald, R., Green, T. C., Nielsen, S., Strang, J., Degenhardt, L., \& Larney, S. (2017). A mapping review of take-home naloxone for people released from correctional settings. International Journal of Drug Policy, 46, 716. https://doi.org/10.1016/j.drugpo.2017.05.015.

Increases in fentanyl drug confiscations and fentanyl-related overdose fatalities. (2018). Center for Disease Control and Prevention. https://emergency.cdc gov/han/han00384.asp

Ireland, E. (2020, December 7). A drug Overdose killed vista jail inmate, medical examiner says_-Times of San Diego. Times of San Diego. https:/timesofsandiego.com/crime/2 020/12/07/a-drug-overdose-killed-san-diego-jail-inmate-county-says/

Ireland, E. (2021, January 13). A drug Overdose killed Otay Mesa jail inmate, Medical Examiner Says. Times of San Diego. https:/timesofsandiego.com/crime/2021/ 01/12/a-drug-overdose-killed-otay-mesa-jail-inmate-medical-examiner-says/

Iroquois County inmate died of fentanyl, heroin overdose. (2020, September 29). https://newschannel20.com/news/local/iroquois-county-inmate-died-of-fenta nyl-heroin-overdose 
Jail sweep underway after Pasco inmate dies from drug overdose. (2019, February 1). [Text.Article]. FOX 13 Tampa Bay; FOX 13 Tampa Bay. https://www.fox13 news.com/news/jail-sweep-underway-after-pasco-inmate-dies-from-drugoverdose

Kemp, K. (n.d.). Deputy assisting inmate with drug Overdose fell ill yesterday in the Mendocino County jail. Redheaded Blackbelt. Retrieved April 12, 2021, from https://kymkemp.com/2020/12/09/deputy-assisting-inmate-with-drugoverdose-fell-ill-yesterday-in-the-mendocino-county-jail/

Kim, D., Irwin, K. S., \& Khoshnood, K. (2009). Expanded access to naloxone: Options for critical response to the epidemic of opioid overdose mortality. American Journal of Public Health, 99(3), 402-407. https://doi.org/10.2105/A JPH.2008.136937.

Kim, S., Ting, A., Puisis, M., Rodriguez, S., Benson, R., Mennella, C., \& Davis, F. (2007). Deaths in the Cook County jail: 10-year report, 1995-2004. Journal of Urban Health, 84(1), 70-84. https://doi.org/10.1007/s11524-006-9115-9.

Kinlock, T. W., Gordon, M. S., Schwartz, R. P., Fitzgerald, T. T., \& O'Grady, K. E. (2009). A randomized clinical trial of methadone maintenance for prisoners: Results at 12 months postrelease. Journal of Substance Abuse Treatment, 37(3), 277-285. https://doi.org/10.1016/j.jsat.2009.03.002.

Kinlock, T. W., Gordon, M. S., Schwartz, R. P., O'Grady, K., Fitzgerald, T. T., \& Wilson, M. (2007). A randomized clinical trial of methadone maintenance for prisoners: Results at 1-month post-release. Drug and Alcohol Dependence, 91(2-3), 220-227. https://doi.org/10.1016/j.drugalcdep.2007.05.022.

Kinlock, T. W., Gordon, M. S., Schwartz, R. P., \& O'Grady, K. E. (2008). A study of methadone maintenance for male prisoners: 3-month Postrelease outcomes. Criminal Justice and Behavior, 35(1), 34-47. https://doi.org/10.1177/0093854 807309111

Klein, D. (2018, December 2). Man sentenced for manslaughter in overdose death of inmate. WSAZ. https://www.wsaz.com/content/news/One-dead-severaltreated-after-overdoses-at-Boyd-County-Jail-501733371.html

Kobayashi, L., Green, T. C., Bowman, S. E., Ray, M. C., McKenzie, M. S., \& Rich, J. D. (2017). Patient simulation for assessment of layperson Management of Opioid Overdose with intranasal naloxone in a recently released prisoner cohort. Simulation in Healthcare: Journal of the Society for Simulation in Healthcare, 12(1), 22-27. https://doi.org/10.1097/SIH.0000000000000182.

Kolind, T., \& Duke, K. (2016). Drugs in prisons: Exploring use, control, treatment and policy. Drugs: Education, Prevention and Policy, 23(2), 89-92. https://doi. org/10.3109/09687637.2016.1153604.

Korte, K. (2018, September 14). Cocaine laced with fentanyl leads to multiple deaths, overdoses. Drug Enforcement Administration. https://www.dea.gov/ press-releases/2018/09/14/cocaine-laced-fentanyl-leads-multiple-deathsoverdoses

Larney, S., \& Farrell, M. (2017). Prisoner suicide: A multilevel problem. The Lancet. Psychiatry, 4(12), 894-895. https://doi.org/10.1016/S2215-0366(17)30435-2.

Larney, S., Gisev, N., Farrell, M., Dobbins, T., Burns, L., Gibson, A., ... Degenhardt, L. (2014). Opioid substitution therapy as a strategy to reduce deaths in prison: Retrospective cohort study. BMJ Open, 4(4), e004666. https://doi.org/10.1136/ bmjopen-2013-004666.

Larney, S., Topp, L., Indig, D., O'Driscoll, C., \& Greenberg, D. (2012). A crosssectional survey of prevalence and correlates of suicidal ideation and suicide attempts among prisoners in New South Wales, Australia. BMC Public Health, 12(1), 14. https://doi.org/10.1186/1471-2458-12-14.

Lee, C. (2020). Investigation ordered into Mendocino County deputy's suspected drug overdose. https://www.pressdemocrat.com/article/news/investigationordered-into-mendocino-county-deputys-suspected-drug-overdos/

Lisenby, A. L. O. S. L. P. (2018, December 27). Workhouse inmate died of opioid overdose. St. Louis American. http://www.stlamerican.com/news/local_news/ workhouse-inmate-died-of-opioid-overdose/article_5ff1f39c-0961-11e9-b8d853d4cb7a0aff.html

Loannou, F. (2017, July 20). Fentanyl suspected in inmate overdoses at Santa Clara County jail. SFGate. https://www.sfgate.com/bayarea/article/Fentanylsuspected-in-inmate-overdoses-at-Santa-11303604.php

Lubinski, A. (2020, December 21). 1 dead, others treated after possible fentanyl exposure at county jail. Courier-Tribune. https://www.mycouriertribune.com/ news/1-dead-others-treated-after-possible-fentanyl-exposure-at-county-jail/a rticle_93cbe7c2-7c1a-11ea-8186-07a289298bdd.html

Mazhnaya, A., Bojko, M. J., Marcus, R., Filippovych, S., Islam, Z., Dvoriak, S., \& Altice, F. L. (2016). In their own voices: Breaking the vicious cycle of addiction, treatment and criminal justice among people who inject drugs in Ukraine. Drugs: Education, Prevention and Policy, 23(2), 163-175. https://doi.org/10.31 09/09687637.2015.1127327.
McDonald, J. (2020, February 6). Inmate charged in death of disbarred lawyer who died in custody last week. San Diego Union-Tribune. https://www.sa ndiegouniontribune.com/news/watchdog/story/2020-02-06/inmate-chargedin-death-of-disbarred-lawyer-who-died-in-custody-last-week

McKelway, B. (2015, May 5). Suit seeks \$10 million in Henrico inmate drug death. Richmond Times-Dispatch. https:/richmond.com/news/loca//henrico/suit-seeks-million-in-henricoinmate-drug-death/article_f1d61723-f1a5-5799-9dff-f5e2eb6df4a1.html

Michell. (2016, June 23). Parents of 25-year-old inmate who died in Gunnison jail of drug overdose file suit. The Denver Post. https://www.denverpost.com/201 6/06/23/gunnison-jail-drug-overdose-lawsuit/

Miller. (2018, November 21). Woman who hid drugs in vagina charged with murder after inmate ODs: Cops. The New York Post. https://nypost.com/201 8/11/21/woman-who-hid-drugs-in-vagina-charged-with-murder-after-inmateods-cops/

Minneapolis Man Charged With Smuggling Heroin Into Hennepin County Jail. (n.d.) Retrieved April 12, 2021, from https://www.cbsnews.com/live/cbsn-local-min/

Mitchell, S. (2018, April 22). 5 Sumner inmates taken to hospital after suspected drug overdose. The Gallatin News. https://www.gallatinnews.com/news/ crime/5-sumner-inmates-taken-to-hospital-after-suspected-drug-overdose/a rticle_fb818d6e-4660-11e8-8aea-8fe1a876b584.html

Mumola, C. J. (n.d.). Suicide and Homicide in State Prisons and Local Jails (p. 12). U. S. Department of Justice, Office of Justice Programs.

Murphy, B. (n.d.). State: Inmate fatally overdosed after Nassau jail search failure. Newsday. Retrieved April 12, 2021, from https://www.newsday.com/long-isla nd/crime/nassau-jail-death-drug-contraband-1.50132012

Naylor, S. (2018, January 31). Inmate at Cumberland County Prison died from fentanyl overdose, coroner says. Fox43.Com. https://www.fox43.com/article/ news/local/contests/inmate-at-cumberland-county-prison-died-from-fentanyloverdose-coroner-says/521-ff4cd46b-9c11-4562-b38c-2e5f1ee861be

Nelson, J. (2020, September 21). Charges: 3 inmates overdose after man smuggles heroin into jail. Bring Me The News. https://bringmethenews.com/ minnesota-news/charges-3-inmates-overdose-after-minneapolis-mansmuggles-heroin-into-jail

Nuttle, M. (2021, January 28). 4 Sacramento jail inmates revived after suspected overdoses. Abc10.Com. https://www.abc10.com/article/news/crime/4-inma tes-at-sacramento-county-jail-revived-after-suspected-drug-overdoses/103fa3ac6a3-e3d3-4ccd-8ab9-82ea9c174605

O’Donnell, J. K., Halpin, J., Mattson, C., Goldberger, B., \& Gladden, M. (2017). Deaths involving fentanyl, fentanyl analogs, and U-47700 - 10 states, JulyDecember 2016. MMWR. Morbidity and Mortality Weekly Report, 66(43), 11971202. https://doi.org/10.15585/mmwr.mm6643e1.

OC Inmate's Death Caused By Fentanyl Overdose, Officials Say. (2020, April 18). https://patch.com/california/orange-county/oc-inmates-death-caused-fenta nyl-overdose-officials-say

Ostling, P. S., Davidson, K. S., Anyama, B. O., Helander, E. M., Wyche, M. Q., \& Kaye, A. D. (2018). America's opioid epidemic: A comprehensive review and look into the rising crisis. Current Pain and Headache Reports, 22(5), 32. https://doi. org/10.1007/s11916-018-0685-5.

Ovalle, D. (2017, December 7). Two Miami jail inmates dead from possible fentanyl overdoses | Miami Herald. https://www.miamiherald.com/news/local/crime/a rticle188576814.html

Owens, D. (2019, April 9). Inmate who overdosed on fentanyl at Hartford Correctional Center dies. Hartford Courant. https://www.courant.com/news/ connecticut/hc-hartford-correctional-overdose-death-0410-20190409-ua4 b5sijybhspff4fdy3fm5tvm-story.html

Parmar, M. K. B., Strang, J., Choo, L., Meade, A. M., \& Bird, S. M. (2017) Randomized controlled pilot trial of naloxone-on-release to prevent postprison opioid overdose deaths. Addiction (Abingdon, England), 112(3), 502515. https://doi.org/10.1111/add.13668.

Pasco County man responsible for numerous overdoses at Pasco County jail sentenced to 27 years in federal prison. (2020, March 12). Drug Enforcement Administration. https://www.dea.gov/press-releases/2020/03/12/pascocounty-man-responsible-numerous-overdoses-pasco-county-jail

Pasco Man Pleads Guilty To Causing Series Of Overdoses While Incarcerated At The Pasco County Jail. (2019, November 4). The United States Department of Justice, U.S. Attorney's Office. https://www.justice.gov/usao-mdfl/pr/pasco-ma $n$-pleads-guilty-causing-series-overdoses-while-incarcerated-pasco-county-jail

Patrick, Robert. (2019, May 23). Inmate dies in St. Charles County jail | Law and order | stltoday.com. St. Lousi today. https://www.stltoday.com/news/local/ crime-and-courts/inmate-dies-in-st-charles-county-jail/article_7624df6d-c86255d6-ac94-19d8e353be40.html 
Patrick, Roberts. (2020, July 8). Family of inmate sues over his overdose death in St. Charles County jail | law and order | stltoday.com. https://www.stltoday. com/news/local/crime-and-courts/family-of-inmate-sues-over-his-overdosedeath-in-st-charles-county-jail/article_da556bc9-8ae8-57a7-8f99-8989424ad2 56.html

Perlstein, M. (2019, December 3). Fentanyl overdose in Orleans parish jail not an isolated incident, sources say. Wwltv.Com. https://www.wwltv.com/article/ news/investigations/family-sues-after-father-overdoses-on-fentanyl-in-neworleans-jail/289-008b5cee-0f60-4d0a-98d9-031bcac003bf

Petterson, A. G., \& Madah-Amiri, D. (2017). Overdose prevention training with naloxone distribution in a prison in Oslo, Norway: A preliminary study. Harm Reduction Journal, 14(1), 74. https://doi.org/10.1186/s12954-017-0200-z.

Poli, D. (n.d.). Vermont man dies at greenfield jail. In Greenfield recorder Retrieved April 12, 2021, from https://www.recorder.com/Vermont-man-dies-at-Massa chusetts-jail-29414844.

Prison Opioid Project - Medication for Opioid Use Disorder and the Criminal Justice System. (n.d.). Retrieved April 19, 2021, from http://dev. prisonopioidproject.org/

Rains, B. (2019, March 1). Fentanyl blamed for Sebastian County inmate's death. 4029 news. https://www.4029tv.com/article/fentanyl-blamed-for-sebastiancounty-inmates-death/26596683

Reported Law Enforcement Encounters Testing Positive for Fentanyl Increase Across US | Drug Overdose |CDC Injuny Center. (2019, August 20). Center for Disease Control and Prevention. https://www.cdc.gov/drugoverdose/data/fentanyl-le-reports.html

Rich, J. D., McKenzie, M., Larney, S., Wong, J. B., Tran, L., Clarke, J., Noska, A., Reddy, M., \& Zaller, N. (2015). Methadone continuation versus forced withdrawal on incarceration in a combined US prison and jail: A randomised, open-label trial. Lancet (London, England), 386(9991), 350-359. https://doi.org/10.1016/ S0140-6736(14)62338-2

Riggins, A. (2021, January 13). Authorities say man who died at Otay Mesa jail overdosed on fentanyl. San Diego Union-Tribune. https://www.sa ndiegouniontribune.com/news/public-safety/story/2021-01-13/authorities-sa y-man-who-died-at-otay-mesa-jail-overdosed-on-fentanyl

Rogers, Dave. (2019, September 11). Coroner: Middleton Jail inmate died of drug overdose. https://www.newburyportnews.com/news/local_news/coronermiddleton-jail-inmate-died-of-drug-overdose/article 861909ce-0bf7-509f89e3-eff658a81a56.html

Rogers, Doug. (2015, May 21). Inmate Found Guilty on All Charges in Prison Overdoses. Erie News Now. https://www.erienewsnow.com/story/29125008/ inmate-found-guilty-on-all-charges-in-prison-overdoses

Saavedra, T. (2020). Use of naloxone to combat opioid overdoses soars in Orange County jails - Orange County Register. https://www.ocregister.com/2020/01/1 5/use-of-naloxone-to-combat-opioid-overdoses-soars-in-orange-county-jails/

Salive, M. E., Smith, G. S., \& Brewer, T. F. (1990). Death in prison: Changing mortality patterns among male prisoners in Maryland, 1979-87. American Journal of Public Health, 80(12), 1479-1480. https://doi.org/10.2105/AJPH.80.12.1479.

Sandy, E. (2016, April 21). Fentanyl Overdose Cited in Lorain County Jail Inmate's Death. Cleveland Scene. https:/www.clevescene.com/scene-and-heard/archives/2016/ 04/21/fentanyl-overdose-blamed-for-lorain-county-jail-inmates-death

Saunders, M. (2020, December 12). San Diego deputies treat 6 inmates for potential fentanyl overdose. KGTV. https://www.10news.com/news/localnews/san-diego-deputies-treat-6-inmates-for-potential-fentanyl-overdose

Schaefer, C. (2016, December 19). Coroner: Dustin Rybak died of fentanyl overdose in jail. WRGT. https://dayton247now.com/news/local/coroner-dustin-rybakdied-of-fentanyl-overdose-in-jail

Schafer, A. (2020, December 2). Manitowoc County Jail death of Justin Hall caused by fentanyl overdose. Herald Times Reporter. https://www.htrnews. com/story/news/2020/12/02/manitowoc-county-jail-death-justin-hall-causedfentanyl-overdose/3795633001/

Schmidt, S. J. (2020, February 7). Woman who smuggled fentanyl into Madison County jail, leading to overdoses, gets 11-years. Alton Telegraph. https:// www.thetelegraph.com/news/article/Woman-gets-11-years-for-drugsbrought-into-jail-15039554.php

Schwigert, K. (2019, April 24). Two Lancaster men charged in connection to Lancaster County Prison inmate's fatal fentanyl overdose. Vox. https://www. fox43.com/article/news/local/contests/two-lancaster-men-charged-inconnection-to-lancaster-county-prison-inmates-fatal-fentanyl-overdose/521-a 9997561-6233-43d9-9dc0-7203007386b7

Sheriff's Office Conducts Drug Search in Jail After Drug Overdose. (n.d.). Retrieved April 12, 2021, from https://bladenonline.com/sheriffs-office-conducts-drugsearch-in-jail-after-drug-overdose/
Signorini, R. (2019, May 17). Allegheny County Jail inmate found dead in cell died of drug overdose | TribLIVE.com. TribLIVE. https://triblive.com/local/pittsburgh-a llegheny/medical-examiner-jail-inmate-died-from-drug-overdose/

Sledge, M. (2020, October 18). Fentanyl, veterinary drug were in body of New Orleans jail inmate who overdosed, coroner says. NOLA.Com. https://www. nola.com/article_9433131c-0ffd-11eb-ab3c-3bf4ba8d4d1e.html

Smay, I. (2019, July 30). Inmate who died Spokane Co. Jail in June overdosed, medical examiner says. Krem2. https://www.krem.com/article/news/local/ spokane-county/inmate-who-died-spokane-co-jail-in-june-overdosed-medicalexaminer-says/293-8db03c03-6d92-4c0a-afd7-8bb9e7be9a31

Stanton, S. (2021, January 28). Suspected overdoses at Sacramento County Main Jail send inmates to area hospital. The Sacramento Bee. https://www.sacbee. com/news/local/article248857584.html

Stucker, K. (2019, January 11). Woman sentenced in fatal jailhouse overdose. Fosters.Com. https://www.fosters.com/news/20190111/woman-sentenced-infatal-jailhouse-overdose

Sturgeon, C. (2015, July 14). Three inmates overdose on heroin at York County Jail. WMTW. https://www.wmtw.com/article/three-inmates-overdose-onheroin-at-york-county-jail/2009554

Sutyak, K. (2018, December 10). Inmate at Portage County jail treated for possible fentanyl overdose; nurse given Narcan after exposure to drugs. Fox 8 Cleveland WJW. https://fox8.com/news/inmate-at-portage-county-jail-treated-for-possiblefentanyl-overdose-nurse-given-narcan-after-exposure-to-drugs/

Suzuki, J., \& El-Haddad, S. (2017). A review: Fentanyl and non-pharmaceutical fentanyls. Drug and Alcohol Dependence, 171, 107-116. https://doi.org/10.101 6/j.drugalcdep.2016.11.033.

Treleven, E. (2020, June 8). Estate of jail inmate sues over 2016 drug overdose death. Wisconson State Journal. https://madison.com/wsj/news/local/crime-a nd-courts/estate-of-jail-inmate-sues-over-2016-drug-overdose-death/article 8861c117-9e02-5381-ae89-1cfeaeb83a79.html

U.S. drug overdose deaths continue to rise; increase fueled by synthetic opioids. (2019). The Center for Disease Control and Prevention. https://www.cdc.gov/ media/releases/2018/p0329-drug-overdose-deaths.html

USDA ERS - Rural-Urban Continuum Codes. (n.d.). Retrieved April 12, 2021, from https://www.ers.usda.gov/data-products/rural-urban-continuum-codes.aspx

Ward, K. (n.d.). If an inmate dies of an overdose, who is to blame? This lawsuit says jailers are. Lexington Herald-Leader. Retrieved May 11, 2020, from https://www.kentucky.com/news/local/crime/article211944594.html

WDTV News Staff. (2020, December 6). 2 inmates dead of suspected overdose; 1 held less than a day. https://www.wdtv.com/2020/12/06/overdose-suspectedin-deaths-of-2-inmates-at-wva-jail/

Wenger, L. D., Showalter, D., Lambdin, B., Leiva, D., Wheeler, E., Davidson, P. J., ... Kral, A. H. (2019). Overdose education and naloxone distribution in the San Francisco County jail. Journal of Correctional Health Care, 25(4), 394-404. https://doi.org/10.1177/1078345819882771.

Wester, J. (2019, June 10). Mecklenburg County jail imate overdosed on fentanyl inside the jail, autopsy says. Charlotte Observer. https://www.cha rlotteobserver.com/news/local/crime/article231383653.html

Wester, Jane. (n.d.). Another jail inmate died of fentanyl overdoses this summer, records show. The Charlotte observer. Retrieved April 12, 2021, from https:// www.charlotteobserver.com/news/local/crime/article222946255.html

Wester, Jane, \& Kane, D. (2018, November 6). Autopsies show drug overdoses in two jail deaths. Charlotte Observer. https://www.charlotteobserver.com/ news/local/crime/article221512330.html

Winkelman, T. N. A., Chang, V. W., \& Binswanger, I. A. (2018). Health, Polysubstance use, and criminal justice involvement among adults with varying levels of opioid use. JAMA Network Open, 1(3), e180558. https://doi. org/10.1001/jamanetworkopen.2018.0558.

Winston, H. (2020, July 11). Inmate in PBC jail for six days dies of fentanyl overdose, ME says. https://www.palmbeachpost.com/story/news/courts/2020/06/11/inma te-in-pbc-jail-for-six-days-dies-of-fentanyl-overdose-me-says/41746543/

WKBN Staff. (2019, March 22). Deputies say inmate overdosed on fentanyl at Mahoning County jail. WKBN.Com. https://www.wkbn.com/news/local-news/ deputies-say-inmate-overdosed-on-fentanyl-at-mahoning-county-jail/

Woman died of fentanyl overdose at Cook County Jail: Autopsy. (2019, March 28). [Text.Article]. FOX 32 Chicago; FOX 32 Chicago. https://www.fox32chicago. com/news/woman-died-of-fentanyl-overdose-at-cook-county-jail-autopsy

\section{Publisher's Note}

Springer Nature remains neutral with regard to jurisdictional claims in published maps and institutional affiliations. 